\title{
Mobile Dental Delivery System: An Effective Protocol for Hygiene and Disinfection
}

\author{
Damien Offner 1,2,3,*(-), Gabriel Fernandez De Grado ${ }^{1,2,3}$, Marion Strub ${ }^{1,2,3}$, Laure Belotti ${ }^{4}$, \\ Stéphanie Deboscker ${ }^{5}$ and Anne-Marie Musset ${ }^{1,2,3}$ \\ 1 Université de Strasbourg, Faculté de Chirurgie Dentaire, 8 rue Ste Elisabeth, F-67000 Strasbourg, France; \\ gabfdg@free.fr (G.F.D.G.); marion.strub@chru-strasbourg.fr (M.S.); \\ anne.marie.musset@chru-strasbourg.fr (A.-M.M.) \\ 2 INSERM (French National Institute of Health and Medical Research), UMR 1260, Regenerative \\ Nanomedicine (RNM), FMTS, F-67000 Strasbourg, France \\ 3 Pôle de Médecine et Chirurgie Bucco-Dentaires, Hôpitaux Universitaires de Strasbourg (HUS), \\ 1 Place de l'Hôpital, F-67000 Strasbourg, France \\ 4 Service d'Hygiène Hospitalière, Laboratoire d'hygiène, Hôpitaux Universitaires de Strasbourg (HUS), \\ 1 Place de 1'Hôpital, F-67000 Strasbourg, France; laure.belottiehrhard@chru-strasbourg.fr \\ 5 Service d'Hygiène Hospitalière, Equipe opérationnelle d'hygiène, Hôpitaux Universitaires de \\ Strasbourg (HUS), 1 Place de l’Hôpital, F-67000 Strasbourg, France; stephanie.deboscker@chru-strasbourg.fr \\ * Correspondence: doffner@unistra.fr
}

Received: 5 February 2020; Accepted: 27 February 2020; Published: 2 March 2020

check for updates

\begin{abstract}
Mobile dental delivery systems (MDDSs) are receiving growing interest for reaching isolated patients, as well as in dental care for fragile and hospitalized patients, with the advantage of being able to be used from room to room or during general anesthesia (GA) in an operating room. Therefore, ensuring the care safety is crucial. The aim of this study was to elaborate and assess an MDDS maintenance protocol, containing the management of dental unit waterlines and adapted to specific conditions such as dental care under GA. A step-by-step protocol was established and implemented for an MDDS used during dental care under GA in children. Samples of the output water were collected at J0, J+1, 3, 6, 12, and 24 months, and cultured to observe the microbiological quality of the water. All the results (heterotrophic plate count at $22^{\circ} \mathrm{C}$, at $37^{\circ} \mathrm{C}$, and specific pathogenic germs sought) showed an absence of contamination. The protocol presented was effective over time and allowed ensuring the safety of care to be ensured when using MDDS, even during dental procedures under GA. As a result, it could be implemented by any dental care delivery structure wanting to reinforce the safety of its practice.
\end{abstract}

Keywords: anesthesia; general; dental equipment; water microbiology; dentistry; operative rooms; pediatric dentistry; vulnerable populations

\section{Introduction}

Even if most dental procedures are performed in private practices, mobile dental delivery systems (MDDSs) (Figure 1) are receiving growing interest in the field of dentistry [1,2]. Many reasons can be attributed to this interest. Indeed, MDDSs associated or not to mobile units or vans allow unserved populations to be reached [2], providing cost-efficient services even if the time spent in setting up the unit could be a limitation [3]. MDDSs enable some barriers to accessibility to be broken, such as geographical barriers: patients from rural communities, isolated areas, etc. [1-4]; socio-economic barriers: children and elderly from families with low socio-economic status [1], patients medically underserved in poor urban areas [1], immigrants [1,5], homeless people [1]; and health barriers: vulnerable patients at home or in care facilities [1], hospitalized patients [1,3], and elderly patients $[1,3]$. 
In addition, to reach patients who live in areas not provided with dental surgeons, or to gain access to destitute and vulnerable patients, MDDSs can be used in a hospital environment, from room to room, or associated to the delivery of dental care under general anesthesia (GA) in an operating room.

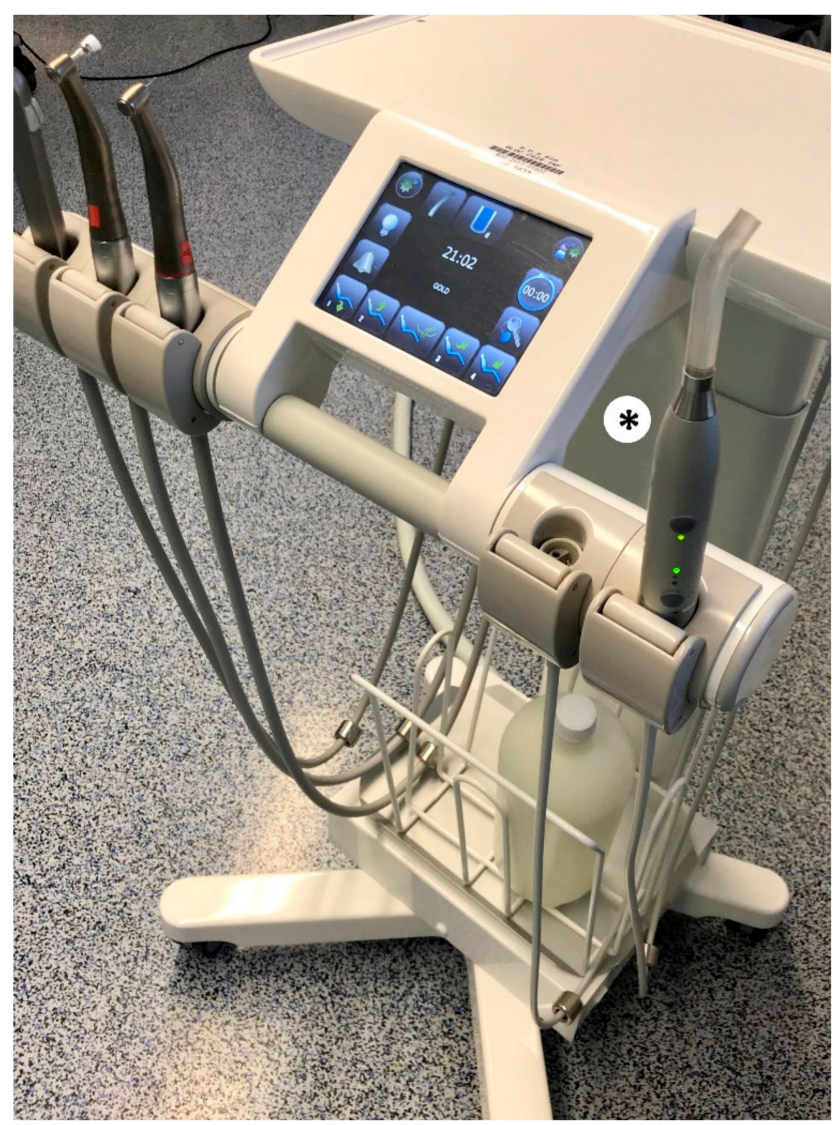

Figure 1. Mobile dental delivery service. ${ }^{*}$ water reservoir.

Many patients require dental treatment benefitting from GA [6], mostly patients feeling fear or extreme anxiety [7-9], with an excessive treatment need [7], or with an extremely severe dental problem $[8,10]$. Some patients accumulate several indications for GA dental procedures, especially uncooperative children $[7,8,11]$; physically and/or intellectually impaired patients with increased rate of tooth destruction due to trauma, tooth grinding, or acid regurgitation [9,12]; or patients with ineffective conscious sedation $[7,13]$.

GA is a comfortable procedure for both the patient and the dentist, avoiding any cooperation problems, taking only a single appointment [7], and having a positive impact on parental emotion and conflict in case of young patients [8], but it is not without risks. Indeed, pain, nausea, and dizziness represent the major morbidity items after dental procedures under GA $[9,14]$. Death is also a possible complication, even if it is rather unlikely to happen [14]: during the years 1999 to 2005, there was a mean of 34 deaths per year due to GA among all the children who benefitted from GA in the USA [15]. However, there is a growing demand from patients to be treated under GA, leading to a long wait of several months, which increases the consumption of painkillers or antibiotics and the complications for patients [16]. In fact, several studies have focused on these delays: in the Netherlands, Boehmer et al. (2003) highlighted that the demand for GA exceeds the supply and that the waiting time was on average 8 weeks [17]. In the United Kingdom, according to Albadri et al. (2006) [18] and Lewis et al. (2002) [19] the waiting time was 10 weeks on average. For Foster Page in New Zealand, the average time was 2.8 months or approximately 11.5 weeks [20] between 2001 and 2005. For Haubek et al. in Denmark, the average time is 16 weeks [21]. In Australia, waiting times of 8 to 12 weeks are described, and in the USA, this time is 10 weeks on average [19]. 
Thus, dental procedures under GA, often associated with the use of an MDDS, represent a public health matter. Because concerned people are mostly vulnerable and weakened, and because there are comorbidities associated with these procedures [9,22], it is important that dental treatment under GA is performed as safely as possible [14]. For example, some cancer patients or hemophiliac patients could require hospitalization and could undergo dental procedures under GA. Based on the high risk of bleeding in patients with coagulopathies, guidelines have been established, particularly including the use of antibacterial mouthwash in the preoperative part, but no mouth rinsing for $24 \mathrm{~h}$ in the postoperative period [23]. As such, ensuring the diminution of the bacterial load in these vulnerable patients' mouths is important.

This point leads to a focus on the hygiene of equipment such as MDDSs, in order to reinforce the safety of care. An MDDS is composed of the dental unit itself, a suction system, external surfaces, and dental unit waterlines (DUWL). If external surfaces and the suction system do not represent a challenge in terms of hygiene and disinfection when using appropriate products and methods [24-26], DUWL are regularly mentioned as the Achilles heel of the dental unit, due to its microbial contamination [27-30]. In fact, many studies report the presence of planktonic or sessile bacterial flora in DUWL, coming either from the water supply network [27,29], or as a result of a back-contamination of DUWL, caused by a backflow of oral fluids when rotary instruments stop [28,30,31]. DUWL, which are long and thin pipes, do present an important surface-to-volume ratio. This factor, associated with the presence of a laminar water flow, can promote biofilm formation [32]. Consequently, there is a real risk of infection for the patient and the dental team, which can even lead to the death of weakened patients [27]. Moreover, regarding the waiting time of several months before an appointment for dental procedures under GA, it is inconvenient to have to stop using an MDDS because it is contaminated. This would lead to an even longer waiting time, and associated complications for the patients.

If the dental chair, in its rudimentary form, has been used since the 19th century [33], it is only in the second half of the 20th century that the contemporary dental units took shape. Their first innovations were only technical (power, ergonomics, choice of instruments, etc.), but hygiene improvements were achieved from the 1970s, especially regarding external surfaces and the suction system [26,34]. It is only during the 2000s that hygienists and dentists focused on the microbial quality of the water in the dental unit waterlines, but mostly for fixed dental units. Indeed, MDDSs were then scarcely used, but their utilization has been developed since.

Once a week, dental practitioners from the Pediatric Dentistry department of the Strasbourg University Hospitals provide a session of care dedicated to children under GA, using an MDDS. Since the MDDS is used only one day a week, there is an increased risk linked to the possibility of backwater in the DUWL, and thus the development of a biofilm standing for a secondary reservoir of contamination. The use of a continuous water disinfection system previously showed good results in terms of microbiological quality control of the water that is used for dental procedures [30]. However, these results apply in general procedures, and there are no data about a prolonged contact of the disinfection product with the oropharyngeal mucosa during GA, especially regarding the possibility of its absorption in the presence of a pharyngeal packing (Figure 2). The latter is usually placed in the pharynx before starting dental procedures and is aimed to protect the airway from blood and debris, which could lead to obstruction and complications [35]. Therefore, we decided to use sterile water during these interventions and to implement a maintenance protocol to guarantee the safety of care when using MDDSs. Furthermore, even when using sterile water, a risk of water contamination in the DUWL still exists because of the possible back-contamination [28,30,31]. 


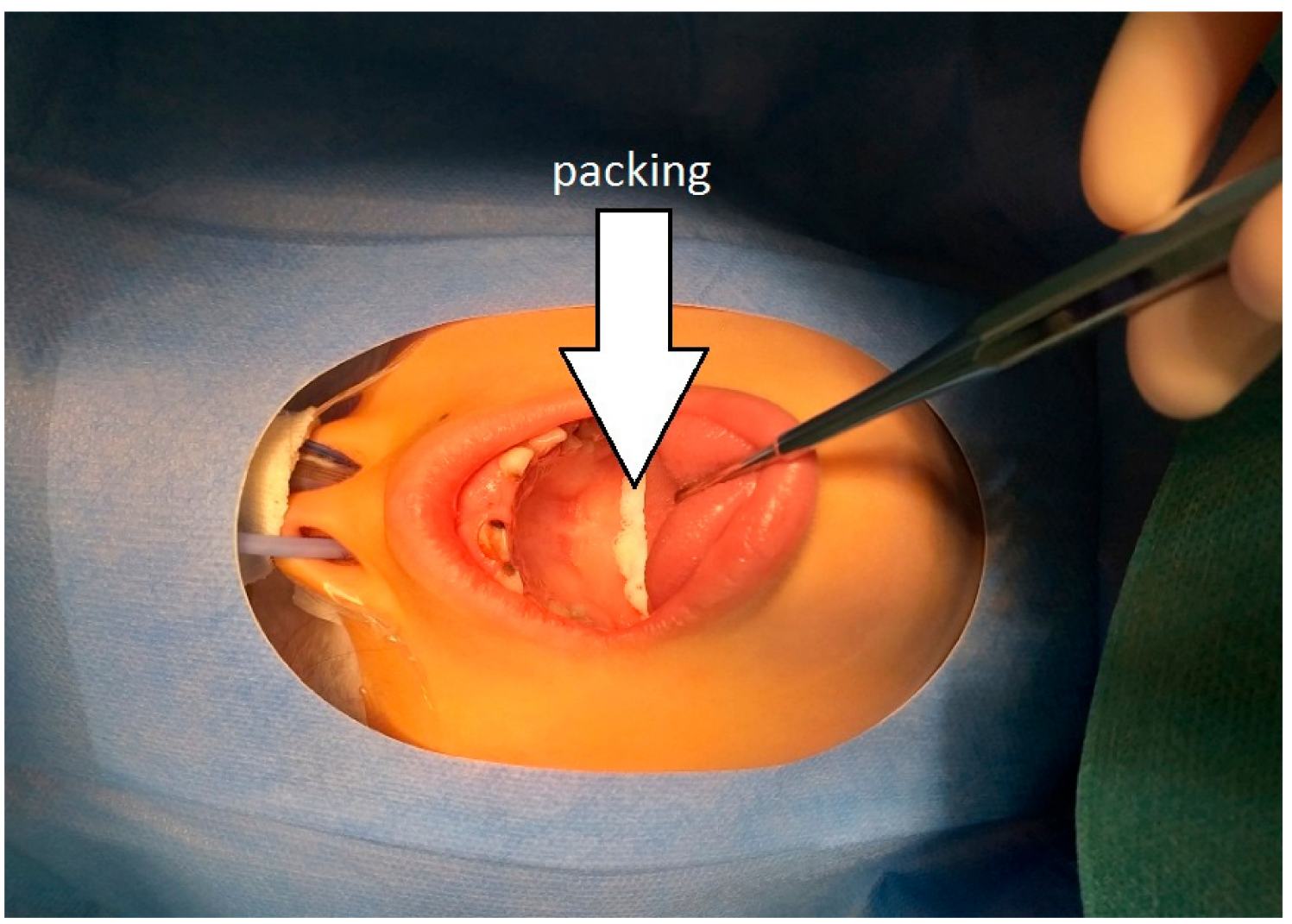

Figure 2. Pharyngeal packing in a child under general anesthesia (GA).

Thus, this study aimed to elaborate and assess over time this MDDS maintenance protocol, containing the management of dental unit waterlines and adapted to specific conditions such as dental care under GA.

\section{Material and Methods}

In the Strasbourg University Hospital, a new MDDS equipped with reservoirs for the water supply (Figure 1) was provided in February 2018 and reserved solely for dental procedures in children under GA. It is used one half-day a week, which corresponds to a mean of three patients per session. To ensure the safety of care, and in order not to allow the disinfection product, Calbénium $(C)$ (Airel-Quetin, Champigny-Sur-Marne, France), to be in contact with the packing (Figure 2), the following protocol was elaborated and applied from February 2018.

\subsection{Maintenance Protocol}

Before use:

- Remove the reservoir and disinfect it by soaking (as well as its cap) in a solution of Aniosyme X3C) (Anios) for $5 \mathrm{~min}$, in a tray dedicated to reservoirs.

- Rinse this reservoir and its cap with bacteriologically controlled water (tap provided with a bacteria filter), dry it with medical air, close it with its cap, and package it in a sterile pouch in order to stock it in clean and dry conditions.

- Fill another clean and disinfected reservoir with sterile water and Calbenium $(c$ at a concentration of $2 \%$. Put it in place in the MDDS.

- Purge the air/water spray and the handpiece hoses for 1 min each in the suction can (Figure 3A).

- Leave for $5 \mathrm{~min}$ to act. 
- During that time, remove the reservoir that contains the Calbenium(C) solution (which will not be used for the dental procedures), close it tight, and keep it for the next purges during the same session (Figure 3B).

- $\quad$ Put in place a reservoir, clean and disinfected, filled with sterile water (Figure 3C-E).

- Purge the air/water spray and the handpiece hoses in the suction can for 30 seconds each, to remove the Calbenium (C) from the DUWL.

- Clean and disinfect the surfaces using a detergent-disinfectant product.

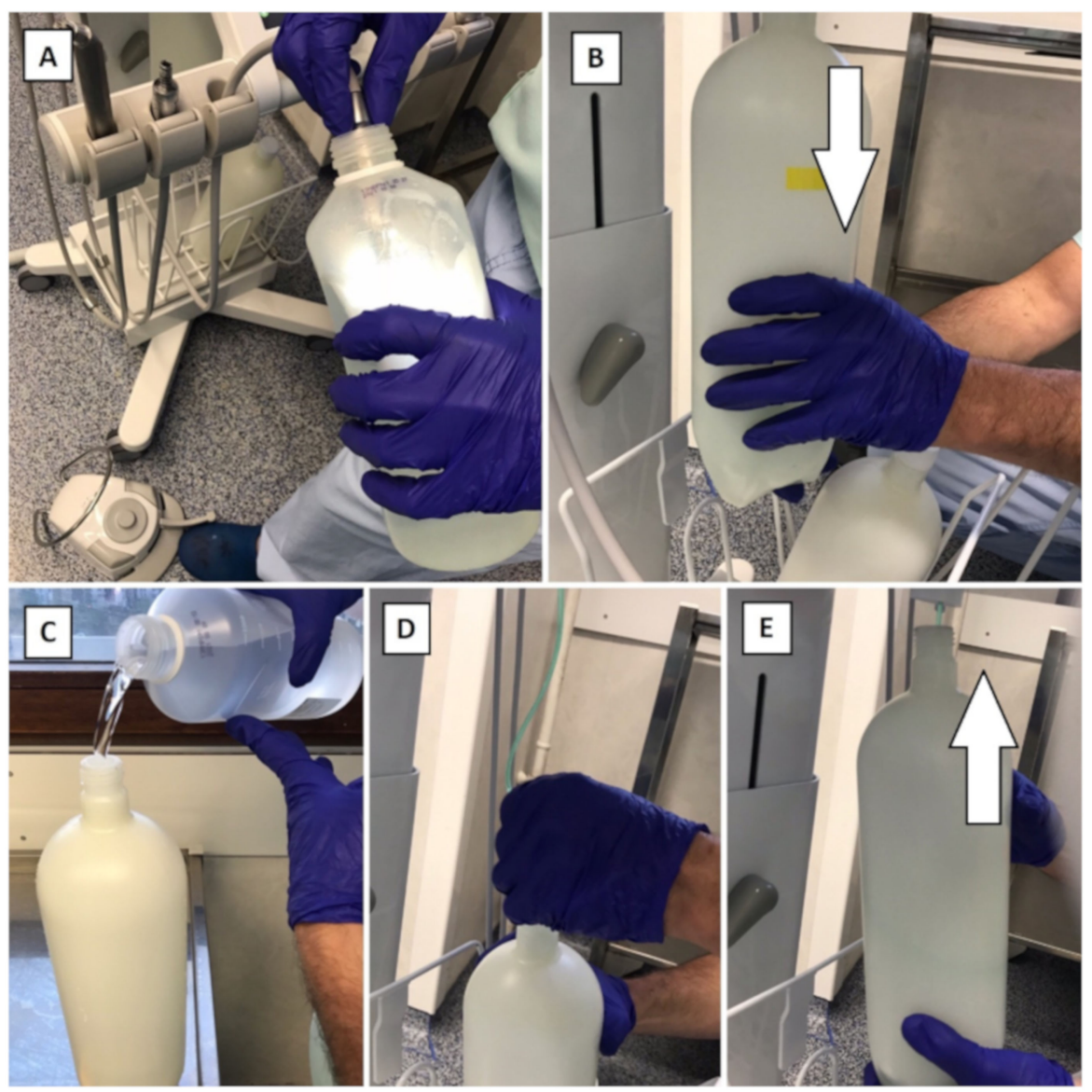

Figure 3. Parts of the maintenance protocol of the mobile dental delivery system (MDDS), before use and between each patient. (A) Purge of the air/water spray and the handpieces hoses with the Calbenium (C) solution; (B) removal of the reservoir that contains the Calbenium (C) solution; (C) filling of another reservoir with sterile water; $(\mathbf{D}, \mathbf{E})$ placement of the reservoir containing sterile water.

Between each patient:

- $\quad$ Remove the reservoir and disinfect it by soaking (as well as its cap) in a solution of Aniosyme X3(C) during $5 \mathrm{~min}$, in a tray dedicated to reservoirs.

- $\quad$ Rinse this reservoir and its cap with bacteriologically controlled water (tap provided with a bacteria filter), dry it with medical air, close it with its cap, and package it in a sterile pouch to stock it in clean and dry conditions.

- Put in place the reservoir that contains the $2 \%$ Calbenium C solution.

- $\quad$ Purge the air/water spray and the handpiece hoses in the suction can for 30 seconds each, before disconnecting and treating dental handpieces (Figure 3A).

- $\quad$ Leave for $5 \mathrm{~min}$ to act. 
- During that time, remove the reservoir that contains the Calbenium $\subset$ solution (Figure 3B), which will not be used for the dental procedures, close it tight, and keep it for the next purges during the same session.

- Put a reservoir in place, clean and disinfected, filled with sterile water (Figure 3C-E).

- Purge the air/water spray and the handpiece hoses in the suction can for $30 \mathrm{~s}$ each, in order to remove the Calbenium $($ ) from the DUWL.

- Clean and disinfect the surfaces using a detergent-disinfectant product.

After the last patient:

- Remove the reservoir and disinfect it by soaking (as well as its cap) in a solution of Aniosyme X3C for $5 \mathrm{~min}$, in a tray dedicated to reservoirs.

- Rinse this reservoir and its cap with bacteriologically controlled water (tap provided with a bacteria filter), dry it with medical air, close it with its cap, and package it in a sterile pouch in order to stock it in clean and dry conditions.

- Put in place the reservoir that contains the $2 \%$ Calbenium (C) solution.

- Purge the air/water spray and the handpiece hoses in the suction can for $30 \mathrm{~s}$ each, before disconnecting and treating dental handpieces (Figure 3A).

- Leave for $5 \mathrm{~min}$ to act.

- $\quad$ Remove the reservoir that contains the Calbenium (C) solution (Figure 3B) and disinfect it by soaking (as well as its cap) in a solution of Aniosyme X3(C) for $5 \mathrm{~min}$ in a tray dedicated to reservoirs.

- Rinse this reservoir and its cap with bacteriologically controlled water (tap provided with a bacteria filter), dry it with medical air, close it with its cap, and package it in a sterile pouch in order to stock it in clean and dry conditions.

- Put a reservoir in place, clean, disinfected, and empty.

- Drain the DUWL with air for $30 \mathrm{~s}$. Leave the reservoir in place.

- Clean and disinfect the surfaces using a detergent and a disinfectant.

The Calbenium (C) solution is composed of EDTA, benzalkonium chloride, sodium tosylchloramide, allantoin, aspartame, sorbitol, and spearmint flavor. Proportions of these products are not disclosed by the manufacturer. It is active against bacteria, fungi, and viruses according to standards AFNOR NFT72150, AFNOR NFT72151, AFNOR NFT72170, AFNOR NFT72200, and AFNOR NFT72180.

Aniosyme X3(C) is composed of quaternary ammonium propionate, digluconate chlorhexidine, nonionic surfactants, and an enzymatic complex (protease, lipase, and amylase). It is active against bacteria, viruses, and yeasts according to standards EN1040, EN13727, EN14561, EN1275, EN13624, EN14562, and EN14476.

\subsection{Study Design}

Samples of the output water of the MDDS were collected at different times:

- J0, after a first realization of the maintenance protocol ("Between each patient" part), and before the first effective use of the MDDS in patients.

- $\quad \mathrm{J} 0+1$ month, J0 +3 months, J0 +6 months, J0 +12 months, and J0 +24 months, to monitor the evolution of a potential contamination.

All these samples were collected in the morning, after the "Before use" part of the protocol, and before treating the first patient. Water samples culture conditions as well as the standards used [36-40] are described in Table 1. Microbiological quality levels were set according to European directives and hospital practice [36], and are even stricter than the standards given by the American Dental Association (ADA) [41]: compliant results with the expected values were viable aerobic microorganism count at $22{ }^{\circ} \mathrm{C} \leq 100 \mathrm{cfu} / \mathrm{mL}$, and at $37^{\circ} \mathrm{C} \leq 10 \mathrm{cfu} / \mathrm{mL}$, and the absence of specific pathogenic germs (Table 1 ). 
Table 1. Culture conditions of the output water samples collected from the MDDS and standards used [36].

\begin{tabular}{|c|c|c|c|c|c|c|}
\hline $\begin{array}{c}\text { Microorganisms } \\
\text { Sought }\end{array}$ & $\begin{array}{c}\text { Volume } \\
\text { Analyzed }\end{array}$ & $\begin{array}{c}\text { Maximum } \\
\text { Storage Duration } \\
\text { before Analysis } \\
\text { Recommended } \\
\text { (h) }\end{array}$ & $\begin{array}{l}\text { Maximum } \\
\text { Storage } \\
\text { Duration } \\
\text { before Analysis } \\
\text { Accepted (h) }\end{array}$ & $\begin{array}{c}\text { Storage } \\
\text { Temperature } \\
\left({ }^{\circ} \mathrm{C}\right) \text { before } \\
\text { Analysis }\end{array}$ & $\begin{array}{l}\text { Samples } \\
\text { Seeding } \\
\text { Conditions }\end{array}$ & Standard \\
\hline $\begin{array}{l}\text { Viable aerobic } \\
\mathrm{MO} \text { at } 22^{\circ} \mathrm{C}\end{array}$ & $1 \mathrm{~mL}$ & 8 & 12 & $5 \pm 3$ & $\begin{array}{l}72 \mathrm{~h} \text { at } 22^{\circ} \mathrm{C} \text { on } \\
\text { agar PCA by } \\
\text { inclusion }\end{array}$ & ISO 6222 [37] \\
\hline $\begin{array}{l}\text { viable aerobic } \\
\mathrm{MO} \text { at } 37^{\circ} \mathrm{C}\end{array}$ & $1 \mathrm{~mL}$ & 8 & 12 & $5 \pm 3$ & $\begin{array}{l}48 \mathrm{~h} \text { at } 36^{\circ} \mathrm{C} \text { on } \\
\text { agar PCA by } \\
\text { inclusion }\end{array}$ & ISO 6222 [37] \\
\hline $\begin{array}{c}\text { Coliform } \\
\text { bacteria and } \\
\text { Escherichia coli }\end{array}$ & $100 \mathrm{~mL}$ & 8 & 18 & $5 \pm 3$ & $\begin{array}{c}24 \mathrm{~h} \text { at } 36^{\circ} \mathrm{C} \text { on } \\
\text { agar TTC by } \\
\text { membrane } \\
\text { filtration, } 2 \text { nd } \\
\text { inspection after } \\
48 \mathrm{~h}\end{array}$ & ISO 9308-1 [38] \\
\hline $\begin{array}{l}\text { Pseudomonas } \\
\text { aeruginosa }\end{array}$ & $100 \mathrm{~mL}$ & 8 & 12 & $\begin{array}{c}5 \pm 3 \text { or } \\
\text { ambient } \\
(\leq 25)\end{array}$ & $\begin{array}{l}48 \mathrm{~h} \text { at } 36^{\circ} \mathrm{C} \text { on } \\
\text { cetrimide agar } \\
\text { by membrane } \\
\text { filtration }\end{array}$ & ISO 16266 [39] \\
\hline
\end{tabular}

Abbreviations: $\mathrm{MO}$, microorganisms; PCA, plate count agar; TTC, tergitol = medium used for the search and count of coliform bacteria.

\section{Results}

Primary samples at J0, before any utilization of the MDDS with any patient, showed no contamination: $<1 \mathrm{cfu} / \mathrm{mL}$ for the viable aerobic microorganism at $22{ }^{\circ} \mathrm{C}$ and at $37{ }^{\circ} \mathrm{C}$, and no signs of, coliforms, Escherichia coli or Pseudomonas aeruginosa. The same microbial quality, $<1 \mathrm{cfu} / \mathrm{mL}$, was found for all the samples at J0 +1 month, 3 months, 6 months, 12 months, and 24 months (Table 2), which means all these results were compliant with the expected values for the viable aerobic microorganisms at $22{ }^{\circ} \mathrm{C}$ and at $37^{\circ} \mathrm{C}$, the presence of coliforms, E. coli, or P. aeruginosa. Therefore, the protocol seems to be effective over time.

Table 2. Results of the output water samples collected from the MDDS at different times.

\begin{tabular}{|c|c|c|c|c|c|c|c|}
\hline Microorganisms Sought & J0 & $\begin{array}{c}\text { J0 + } \\
1 \text { Month }\end{array}$ & $\begin{array}{c}\mathrm{J0}+ \\
3 \text { Months }\end{array}$ & $\underset{\text { 6 Months }}{\mathrm{J} 0+}$ & $\begin{array}{c}\text { J0 + } \\
12 \text { Months }\end{array}$ & $\begin{array}{c}\text { J0 + } \\
24 \text { Months }\end{array}$ & Target Level \\
\hline Viable aerobic $\mathrm{MO}$ at $22^{\circ} \mathrm{C}$ & $<1$ & $<1$ & $<1$ & $<1$ & $<1$ & $<1$ & $\leq 100 \mathrm{cfu} / \mathrm{mL}$ \\
\hline Viable aerobic $\mathrm{MO}$ at $37^{\circ} \mathrm{C}$ & $<1$ & $<1$ & $<1$ & $<1$ & $<1$ & $<1$ & $\leq 10 \mathrm{cfu} / \mathrm{mL}$ \\
\hline Coliform bacteria and E. coli & $<1$ & $<1$ & $<1$ & $<1$ & $<1$ & $<1$ & $<1 \mathrm{cfu} / 100 \mathrm{~mL}$ \\
\hline Pseudomonas aeruginosa & $<1$ & $<1$ & $<1$ & $<1$ & $<1$ & $<1$ & $<1 \mathrm{cfu} / 100 \mathrm{~mL}$ \\
\hline
\end{tabular}

\section{Discussion}

Many cases of DUWL contamination are reported in the literature [27,30,40,42-45], and represent a concern for hygienists and dentists worldwide [45]. If previous studies showed good results of maintenance protocols applied to fixed dental units and dental chairs $[29,44,46]$, the challenge was here to adapt a protocol to MDDSs for which water disinfectants are not used during dental procedures. Indeed, the MDDS was used under specific conditions such as GA environment and especially the presence of packing, and during procedures in vulnerable patients (children, impaired patients, etc.). In general, MDDSs are often used on-demand and not continuously: this causes less water flow and therefore an increased risk of forming a biofilm. If the constitution of a biofilm is never desirable, it is even less so for vulnerable patients.

In fact, the oral microbiota is complex, and a slight change can create an imbalance in favor of pathogenic species at the origin of some oral pathologies [47], especially for vulnerable populations or patients with low immune defenses. Maintaining a low level of bacterial load in a patient's mouth, 
particularly for vulnerable patients, is important. For this reason, dentists usually use antimicrobial mouthwash before and after dental procedures or use newly developed interesting formulations, such as chlorhexidine gels [48]. In addition, diminishing the bacterial contamination of the water that is used for dental procedures seems to be a logical adjuvant.

The protocol that we described is the first one ever described in the literature regarding the maintenance of MDDSs. Our results are far better than the expected values (Table 2) and show that the protocol and the products that we used were effective over time. The maintenance protocol could therefore constitute a basis for any dental care delivery structure wanting to reinforce the safety of its practice. The major flaw is that the protocol may seem rather complex at first glance. In a real application, however, the steps are easily sequenced, and users quickly get used to this protocol, with an average completion time of less than five minutes. Moreover, the application of the protocol can begin immediately after the end of dental care, and during the transfer of the patient in the recovery room, allowing benefiting from hidden time. This completion time is completely compatible with dental care activity, and ultimately represents a small constraint compared to the guarantee of the safety of the care, especially with vulnerable patients. To lighten this protocol, it would be interesting to look at the effects of prolonged contact of disinfectants with the oropharyngeal mucosa in order to avoid the use of sterile water without disinfectant during procedures, and therefore avoid several steps of the protocol. This seems complicated to undertake for ethical reasons, and because this protocol and our results show that there is a practically feasible solution. Nevertheless, it could allow using water from the hospital water supply network, just like it is used in fixed dental units with good outcomes in terms of microbiological quality of the water in DUWL [24,29], and allow moving towards greater efficiency, as sterile water is more expensive than water from the supply network.

\section{Conclusions}

The use of MDDSs meets many indications. It shows a growing interest in the dental care of isolated patients, as well as the provision of dental care in hospitals, from room to room, or during care under GA. When used with these fragile patients, the interest in guaranteeing the safety of care is then redoubled. Moreover, regarding the waiting time of several months before benefitting from dental procedures under GA, it is of utmost importance not to have to stop using an MDDS because it is contaminated. Different methods arise to manage the contamination of DUWL: filtration, flushing, use of sodium perborate or $\mathrm{H}_{2} \mathrm{O}_{2}$, or use of dedicated disinfectant solutions. Some have shown good results, and some show limitations. This study, using a Calbenium(c) solution, shows that a complete and well-managed hygiene protocol makes it possible to maintain over time a very low or even non-existent level of bacteriological contamination in the components of an MDDS and in particular in its DUWL. This protocol could be implemented by any dental care delivery structure that would like to enhance the safety of its practice and would like to avoid having to stop its activity for hygienic reasons. As such, it improves the quality of care for patients in need of dental procedures under GA and meets public health issues by reducing waiting time for appointments.

Author Contributions: Investigation, D.O., S.D., M.S., and L.B.; Methodology, D.O., G.F.D.G., S.D., and A.-M.M.; Supervision, A.-M.M.; Writing-original draft, D.O. and G.F.D.G.; Writing—review and editing, S.D. and A.-M.M. All authors have read and agreed to the published version of the manuscript.

Funding: The author(s) received no specific funding for this work.

Conflicts of Interest: The authors declare no conflicts of interest.

\section{References}

1. Vashishtha, V.; Kote, S.; Basavaraj, P.; Singla, A.; Pandita, V.; Ravneet, K.M. Reach the unreached-A systematic review on mobile dental units. J. Clin. Diagn. Res. 2014, 8, 5-8. [CrossRef] 
2. Ganavadiya, R.; Chandrashekar, B.R.; Goel, P.; Honqal, S.G.; Jain, M. Mobile and portable dental services catering to the basic oral health needs of the underserved population in developing countries: A proposed model. Ann. Med. Health Sci. Res. 2014, 4, 293-304. [CrossRef] [PubMed]

3. Goel, P.; Goel, A.; Torwane, N.A. Cost-efficiency of indigenously fabricated mobile-portable dental unit in delivery of primary healthcare in rural India. J. Clin. Diagn. Res. 2014, 8, 6-9.

4. Mortier, S.D.; Marlene, M.; Ahmed, B.; Pierre, P. Mobile health units-Methodological approach. Int. Comm. Red Cross 2006, 1, 27.

5. Mulligan, R.; Seirawan, H.; Faust, S.; Habibian, M. Mobile dental clinic: An oral health care delivery model for underserved migrant children. J. Calif. Dent. Assoc. 2010, 38, 115-122. [PubMed]

6. Dougherty, N. The dental patient with special needs: A review of indications for treatment under general anesthesia. Spec. Care Dent. 2009, 29, 17-20. [CrossRef]

7. Savanheimo, N.; Sundberg, S.A.; Virtanen, J.I.; Vehkalahti, M.M. Dental care and treatments provided under general anaesthesia in the Helsinki Public Dental Service. BMC Oral Health 2012, 12, 45. [CrossRef]

8. Park, J.S.; Anthonappa, R.P.; King, N.M.; McGrath, C. The family impact of dental general anaesthesia in children: A meta-analysis. Int. J. Paediatr. Dent. 2019, 29, 149-161. [CrossRef]

9. Enever, G.R.; Nunn, J.H.; Sheehan, J.K. A comparison of post-operative morbidity following outpatient dental care under general anaesthesia in paediatric patients with and without disabilities. Int. J. Paediatr. Dent. 2000, 10, 120-125. [CrossRef]

10. Jamjoom, M.M.; al-Malik, M.I.; Holt, R.D.; el-Nassry, A. Dental treatment under general anaesthesia at a hospital in Jeddah, Saudi Arabia. Int. J. Paediatr. Dent. 2001, 11, 110-116. [CrossRef]

11. Jamieson, L.M.; Roberts-Thomson, K.F. Dental general anaesthetic trends among Australian children. BMC Oral Health 2006, 61, 6. [CrossRef] [PubMed]

12. Loyola-Rodriguez, J.P.; Zavala-Alonso, V.; Gonzalez-Alvarez, C.L.; Juarez-Lopez, L.A.; Patiño-Marin, N.; Gonzalez, C.D. Dental treatment under general anesthesia in healthy and medically compromised/developmentally disabled children: A comparative study. J. Clin. Pediatric Dent. 2009, 34, 177-182. [CrossRef] [PubMed]

13. Attri, J.P.; Sharan, R.; Makkar, V.; Gupta, K.K.; Khetarpal, R.; Kataria, A.P. Conscious sedation: Emerging trends in pediatric dentistry. Anesth. Essays Res. 2017, 11, 277-281. [CrossRef] [PubMed]

14. Atan, S.; Ashely, P.; Gilthorpe, M.S.; Scheer, B.; Mason, C.; Roberts, G. Morbidity following dental treatment of children under intubation general anesthesia in a day-stay unit. Int. J. Paediatr. Dent. 2004, 14, 9-16. [CrossRef]

15. Li, G.; Warner, M.; Lang, B.H.; Huang, L.; Sun, L.S. Epidemiology of anesthesia-related mortality in the United States, 1999-2005. Anesthesiology 2009, 110, 759-765. [CrossRef]

16. North, S.; Davidson, L.E.; Blinkhorn, A.S.; Mackie, I.C. The effects of a long wait for children's dental general anaesthesia. Int. J. Paediatr. Dent. 2007, 17, 105-109. [CrossRef]

17. Boehmer, J.; Stoffels, J.A.; Van Rooij, I.A.; Heyboer, A. Complications due to the waiting period for dental treatment under general anaesthesia [article in dutch]. Ned. Tijdschr. Tandheelkd. 2007, 114, 69-75.

18. Albadri, S.S.; Lee, S.; Lee, G.T.; Llewelyn, R.; Blinkhorn, A.S.; Mackie, I.C. The use of general anaesthesia for the extraction of children's teeth. Results from two UK dental hospitals. Eur. Arch. Paediatr. Dent. Off. J. Eur. Acad. Paediatr. Dent. 2006, 7, 110-115. [CrossRef]

19. Lewis, C.W.; Nowak, A.J. Stretching the safety net too far waiting times for dental treatment. Pediatric Dent. 2002, 24, 6-10.

20. Foster Page, L.A. Retrospective audit of Taranaki children undergoing dental care under general anaesthetic from 2001 to 2005. N. Z. Dent. J. 2009, 105, 8-12.

21. Haubek, D.; Fugslang, M.; Poulsen, S.; Rølling, I. Dental treatment of children referred to general Anaesthesia-Association with country of origin and medical status. Int. J. Paediatr. Dent. 2006, 16, 239-246. [CrossRef] [PubMed]

22. Holt, R.D.; Chidiac, R.H.; Rule, D.C. Dental treatment for children under general anaesthesia in day care facilities at a London dental hospital. Br. Dent. J. 1991, 170, 262-266. [CrossRef] [PubMed]

23. Laino, L.; Cicciù, >M; Fiorillo, L.; Crimi, S.; Bianchi, A.; Amoroso, G.; Monte, I.P.; Herford, A.S.; Cervino, G. Surgical Risk on Patients with Coagulopathies: Guidelines on Hemophiliac Patients for Oro-Maxillofacial Surgery. Int. J. Environ. Res. Public Health 2019, 16, 1386. [CrossRef] [PubMed] 
24. Offner, D.; Deboscker, S.; Belotti, L.; Brisset, L.; Lavigne, T.; Musset, A.M. Elaboration et évaluation d'un protocole d'entretien des units et fauteuils dentaire (ADEC®et Planmecaß) aux Hôpitaux Universitaires de Strasbourg. Hygiènes 2013, 21, 21-28.

25. Offner, D.; Musset, A.M. Hygiene management of dental units: Speaking about patients' safety. Rev. Odontostomatol. 2018, 47, 158-171.

26. Offner, D.; Iltis, L.; Bertrand, A.; Musset, A.M. L'hygiène des tuyaux d'aspiration de l'unit dentaire, étude comparative de l'impact de leur structure et entretien. Inf. Dent. 2015, 18, 12-17.

27. Ricci, M.L.; Fontana, S.; Pinci, F.; Fiumana, E.; Pedna, M.F.; Farolfi, P.; Sabattini, M.A.B.; Scaturro, M. Pneumonia associated with a dental unit waterline. Lancet 2012, 379, 684. [CrossRef]

28. Smith, G.; Smith, A. Microbial contamination of used dental handpieces. Am. J. Infect. Control 2014, 42, 1019-1021. [CrossRef]

29. Coleman, D.C.; O’Donnell, M.J.; Shore, A.C.; Russell, R.J. Biofilm problems in dental unit water systems and its practical control. J. Appl. Microbiol. 2008, 106, 1424-1437. [CrossRef]

30. Offner, D.; Fioretti, F.; Musset, A.M. Contamination of dental unit waterlines: Assessment of three continuous water disinfection systems. BDJ Open 2016, 2, 16007. [CrossRef]

31. Offner, D.; Brisset, L.; Musset, A.M. Evaluation of the mechanical cleaning efficacy of dental handpieces. J. Hosp. Infect. 2018. [CrossRef] [PubMed]

32. Nikaeen, M.; Hatamzadeh, M.; Sabzevari, Z.; Zareh, O. Microbial quality of water in dental unit waterlines. J. Res. Med. Sci. 2009, 14, 297-300. [PubMed]

33. French Society for the History of Dentistry (SFHAD). Histoire de L'aménagement Opératoire du Cabinet Dentaire. L'instrumentation: Les “Outils à Dents" des Nécessaires de Biennais. L'énigme du Nécessaire Dentaire de L'empereur de la Fondation Napoléon. Available online: https://www.biusante.parisdescartes.fr/ sfhad/cab_txt03x7.htm (accessed on 20 February 2020).

34. French Society for the History of Dentistry (SFHAD). Histoire de L'aménagement Opératoire du Cabinet Dentaire. Les Années 1960. Les Pionniers du Travail en Posture Assise. Malençon, Comhaire: Le Renouveau de L'esprit Créatif Européen. Les Recherches de L'ecole Américaine: Le Réaménagement de L'agencement Opératoire. Available online: https://www.biusante.parisdescartes.fr/sfhad/cab_txt23.htm (accessed on 20 February 2020).

35. Iwai, T.; Goto, T.; Matsui, Y.; Tohnai, I. Endoscopic removal of throat-packing gauze swallowed during general anesthesia. J. Craniofac. Surg. 2012, 23, 1547-1549. [CrossRef]

36. European Council. Council directive 98/83/EC of 3 November 1998 on the quality of water intended for human consumption. Off. J. Eur. Commun. 1998, L330, 32-54.

37. ISO 6222. In Water Quality_Enumeration of Culturable Micro-Organisms_Colony Count by Inoculation in a Nutrient Agar Culture Medium; International Standard Organization: Geneva, Switzerland, 1999.

38. ISO 9308-1. In Water Quality_Enumeration of Escherichia Coli and Coliform Bacteria-Part 1: Membrane Filtration Method for Waters with Low Bacterial Background Flora; International Standard Organization: Geneva, Switzerland, 2014.

39. ISO 16266. In Water Quality—Detection and Enumeration of Pseudomonas Aeruginosa-Method by Membrane Filtration; International Standard Organization: Geneva, Switzerland, 2006.

40. Petti, S.; Moroni, C.; Messano, G.A.; Polimeni, A. Detection of oral streptococci in dental unit water lines after therapy with air turbine handpiece: Biological fluid retraction more frequent than expected. Future Microbiol. 2013, 8, 413-421. [CrossRef] [PubMed]

41. Statement on Dental Unit Waterlines. American Dental Association. Last Updated: 20 March 2019. Available online: https://www.ada.org/en/member-center/oral-health-topics/dental-unit-waterlines (accessed on 20 February 2020).

42. Barbeau, J.; Gauthier, C.; Payment, P. Biofilms, infectious agents, and dental unit waterlines: A review. Can. J. Microbiol. 1998, 44, 1019-1028. [CrossRef]

43. Wirthlin, M.R.; Marshall, G.W., Jr.; Rowland, R.W. Formation and decontamination of biofilms in dental unit waterlines. J. Periodontol. 2003, 74, 1595-1609. [CrossRef]

44. Pawar, A.; Garg, S.; Mehta, S.; Dang, R. Breaking the Chain of Infection: Dental Unit Water Quality Control. J. Clin. Diagn. Res. 2016, 10, ZC80-ZC84. [CrossRef]

45. Alkhulaifi, M.M.; Alotaibi, D.H.; Alajlan, H.; Binshoail, T. Assessment of nosocomial bacterial contamination in dental unit waterlines: Impact of flushing. Saudi Dent. J. 2020, 32, 68-73. [CrossRef] 
46. Wirthlin, M.R.; Roth, M. Dental unit waterline contamination: A review of research and findings from a clinic setting. Compend. Contin. Educ. Dent. 2015, 36, 216-219.

47. Fiorillo, L. We Do Not Eat Alone: Formation and Maturation of the Oral Microbiota. Biology 2020, 9, 17. [CrossRef] [PubMed]

48. Fiorillo, L. Chlorhexidine Gel Use in the Oral District: A Systematic Review. Gels 2019, 5, 31. [CrossRef] [PubMed]

(C) 2020 by the authors. Licensee MDPI, Basel, Switzerland. This article is an open access article distributed under the terms and conditions of the Creative Commons Attribution (CC BY) license (http://creativecommons.org/licenses/by/4.0/). 